\title{
PERFORMANCE ANALYSIS OF A SOLAR-DRIVEN EJECTOR AIR CONDITIONING SYSTEM UNDER EL-OUED CLIMATIC CONDITIONS, ALGERIA
}

\author{
Mokhtar Ghodbane ${ }^{1, *}$, Boussad Boumeddane ${ }^{1}$, Ahmed Kadhim Hussein $^{2}$
}

\begin{abstract}
In order to understand the behavior and to determine the effective operational parameters of a solar-driven ejector air conditioning system at low or medium temperature, a dynamic model depends on the principles of conservation, the momentum mass and energy is developed. For this purpose, the thermodynamic characteristics of the liquid and vapor refrigerant were identified using the Engineering Equation Solver (EES) software. Linear Fresnel solar reflector has been used as a tool to convert solar energy into thermal energy. Water (R718) was used as a refrigerant. The operational conditions for the studied solar-driven ejector air conditioning system are as follows: evaporator temperature " $\mathrm{T}_{\mathrm{e}}=283.15 \mathrm{~K}$ ", condenser temperature " $\mathrm{T}_{\mathrm{c}}=305.15 \mathrm{~K}$ ", and generator temperature " $\mathrm{T}_{\mathrm{g}}=$ $373.15 \mathrm{~K}$ ”. The performance of the ejector air conditioning system was compared as a function of the operating parameters of the subsystem. The average value of thermal efficiency of the Fresnel linear concentrator has reached $31.60 \%$, the drive ratio " $\omega$ " is 0.4934 , the performance value of the ejector air conditioning subsystem "COPejc" is $60.664 \%$ and the average value of the thermal performance of the machine "STR" has touched $19.17 \%$. The results obtained through this scientific subject are stimulating and encouraging, where this technique can be used for air conditioning in desert areas in southern Algeria, where fossil energy (petroleum, gas, etc.) is extracted and produced in various types.
\end{abstract}

\section{Keywords: Solar Energy, Air Conditioning, Linear Fresnel Reflector, Ejector, Performance}

\section{INTRODUCTION}

The use of solar energy in sunny countries such as Algeria is an effective way to overcome the lack of energy especially in rural areas where it is sometimes difficult and expensive to feed them with the conventional electricity grid [1, 2]. In addition, Algeria is a country where the solar potential is very important; the annual sunshine is always greater than $2 \times 10^{4} \mathrm{~kJ} / \mathrm{m}^{2}$ of catchment area [3]. As the tendency to exploit this clean and abundant solar energy in daily living (industrial and household) is a priority and not a choice [2, 4-7]. Therefore, it is possible to employ this solar energy in the field of air conditioning of various types in order to reduce the use of fossil electricity.

Among the industrial and household sectors that consume large quantities of electricity in the world are air conditioning systems. These systems drain about $17 \%$ of global electricity consumption. For this reason, the world has turned its attention to the search for clean and continuous alternative energy for the production of electricity, as well as to reduce the use of mechanical elements that consume electricity in large quantities, while working on the use of environmentally friendly refrigerants.

In addition, due to the high cost of air conditioning (cooling and heating) by electric power, as well as the lack of this energy in isolated areas and far from the electrical grids, many of the attention focused on the utilization of solar thermal energy in the areas of air conditioning of various types. Many scientific researchers have touched on this important scientific subject, including the scientific work carried out by Mosleh et al. [8], Bellos et al. [9-14] , Ghodbane et al. [15], Urbanucci et al. [16], Arabkoohsar and Andresen [17], Yıldırım [18] and Kerme and Kaneesamkandi [19].

Through the literature, it turns out that one of the most important modern solar technologies that have a wide chest in the field of air conditioning is the solar-driven ejector air conditioning system because of its simplicity of design and implementation [20-23]. So, solar-driven ejector air conditioning system using low or medium temperature heat rejection or a free energy source (solar) have become in recent years an interesting subject of study, as many

This paper was recommended for publication in revised form by Regional Editor Tolga Taner

${ }^{1}$ Mechanical Engineering Department, Faculty of Technology, Saad Dahlab University of Blida 1, Blida 09000, Algeria

${ }^{2}$ College of Engineering, Mechanical Engineering Department, University of Babylon, Babylon City, Hilla, Iraq

*E-mail address: ghodbanemokhtar39@yahoo.com

Orcid ID: 0000-0003-1350-8631, 0000-0002-1947-6397, 0000-0002-4360-0159

Manuscript Received 26 December 2018, Accepted 01 April 2019 
valuable scientific researchers have touched on this positive technology in the field of conditioning of various types and formulas. Among these works, it found that Bellos et al. have conducted a study aimed at investigating a new solarpowered cooling system with the ejector [24, 25]. In another valuable scientific work, Bellos and Tzivanidis have conducted a study on the optimal design of a solar energy cooling system for different operating situations [26]. In addition, the Energy Journal published a very valuable scientific work by Besagni from which he addressed the needs and standards that should be considered in the long term future activities of the multi-level ejector [27]. With regard to the use of the ejector in the fields of refrigeration, Besagni et al. have done a very valuable scientific work and summarized in it all the uses of the ejector for refrigeration applications [28].

In summary, among the machines that are currently used in the field of air conditioning, the solar-driven ejector air conditioning machine on the one hand, because of the cold needs in buildings that exist in industrial fields (oil complexes, etc.) and the availability of thermal resources either of solar origin in developing countries, or from low-temperature thermal discharges in industrialized countries, and secondly, thermodynamicists encourage the study of refrigeration production systems directly using solar energy. The means by which this operation is carried out is the use of ejector refrigeration machines, also called thermodynamic machines with three temperature sources in which:

- The hot source can be powered by the sun or by heat discharges;

- The cold source is produced at the cold source (by the evaporator);

- The residual heat from the condenser transferred to the ambient medium constitutes the third source.

Based on what has been said previously, in this subject you will be interested in studying about the use of solar-driven ejector air conditioning machine in the southeast of Algeria will be discussed, where the region chosen

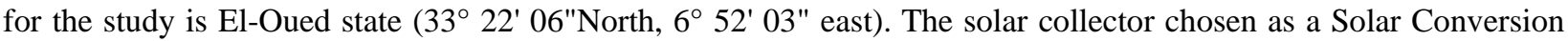
Tool is Linear Fresnel solar Reflector (LFR). All the thermodynamic properties of the air conditioning system will be determined based on the energy equilibrium equations that govern this system. The Engineering Equation Solver EES software has been used as a programming tool. In addition, July 17, 2018 was selected as the ideal day for this study.

\section{GOVERNING EQUATIONS OF THE AIR CONDITIONING SYSTEM}

\section{Ejector air conditioning subsystem}

In this section, a description of the operating principles of the ejector solar air conditioning machine is presented. The operating mode of this machine is offered in the form of equations using the laws of thermodynamics and momentum conservation, mass conservation and energy, to determine the performance characteristics.

Water (R718) has been adopted as refrigerant, where it plays a key role in improving the performance of a solar ejector air conditioning system. Water can be defined as a liquid, odorless and odorless liquid chemical compound, which is the most readily available and widespread on the planet, covering $71 \%$. In addition, it is an environmentally friendly source with very important thermos-physical characteristics that help it to be a first-class refrigerant medium, although it is characterized by its large volume when evaporating.

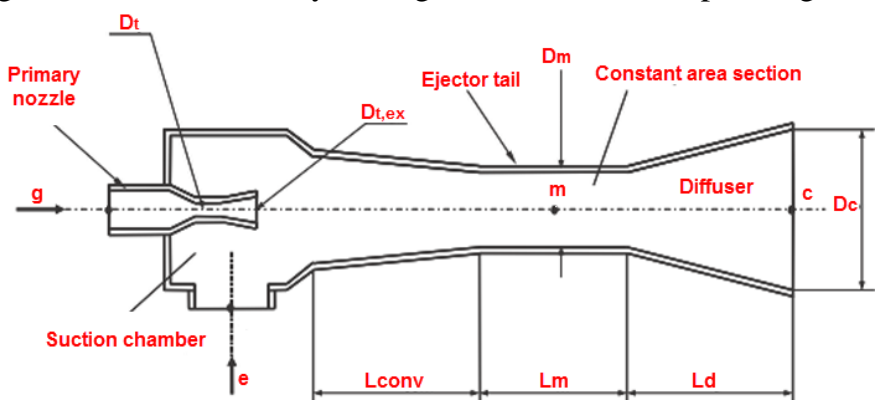

Figure 1. Illustrative schematization of a typical ejector

The ejector solar air conditioner is a very effective solution in rural areas and in desert industrial complexes because it has simple assembly and it has an acceptable performance [15, 29, 30], that's why this system is considered the most attractive than conventional compression technology because it is less expensive [31-34]. 
Generally, the model of the ejector air conditioning subsystem is based on the thermodynamic states in each operating point as shown in Figure 2. The ejector air-conditioning subsystem has two closed cycles: the driving loop (7-1-2-3-4-5-6-7) and the refrigerating loop (7-8-9-5-6-7).

The driving loop (DL): in the power cycle, the energy supplied to the generator is used to evaporate a portion of the refrigerant which represents the driving fluid (primary), which is at high pressure (from state 1 to state 4), then passes through the ejector where it is mixed with the other part of the refrigerant which represents the fluid entrained (secondary), coming from the evaporator and where also performs a pressure recovery (from state 4 to state 6). Then, the entire refrigerant passes through the condenser where it is condensed to the liquid state (from state 6 to state 7). This liquid will be pumped (pressure increase) to the generator and thus completes the cycle (from state 7 to state 1).

a)

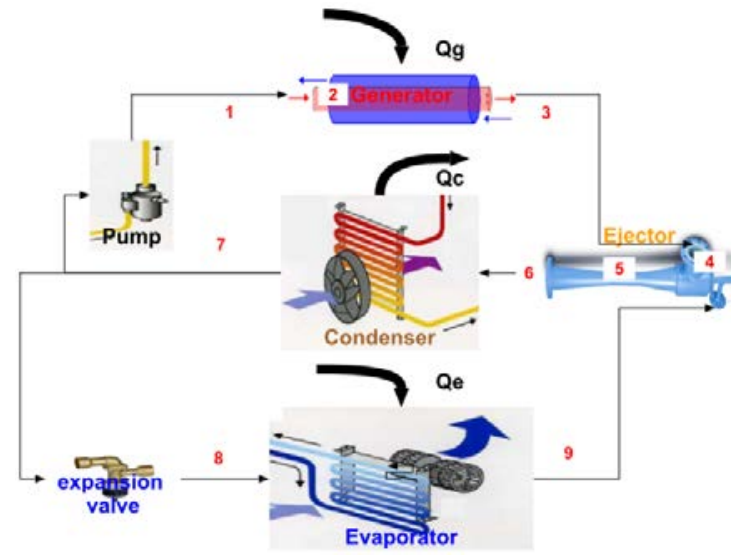

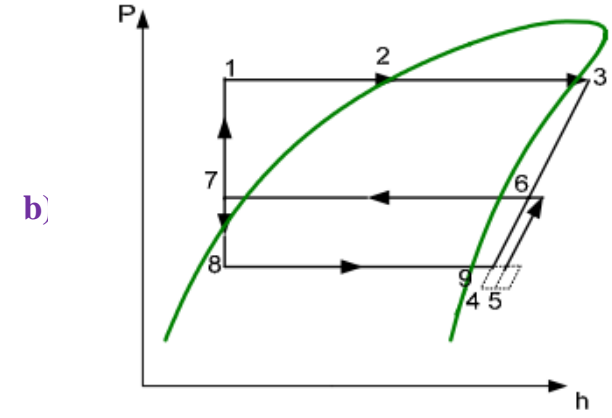

Figure 2. Operating cycle of an ejector air conditioner: a) Elements of air conditioning machine, b) (h, P) diagram

The cooling loop $(\mathrm{CL})$ : in the refrigeration cycle, part of the refrigerant in the liquid state which represents the entrained fluid (secondary) passes through an expansion valve to bring it to a state of low pressure (from state 7 to state 8). The refrigerant subsequently enters the evaporator where it produces by evaporating the desired cold (from state 8 to state 9). The refrigerant is mixed with the other part (the driving fluid) in the ejector where it is compressed (from state 9 to state 6) and the mixture passes through the condenser where it is condensed to the liquid state and complete thus the cycle (from state 6 to state 7).

These two loops (DL and CL) illustrate the thermodynamic working principle of the ejector air conditioner machine. In this study, the thermal generator is an integrated solar system consisting of several elements, the most important of which is the linear Fresnel solar reflector (LFR).

In order for the ejector cycle to function well, this pressing condition $\left(\mathrm{P}_{\mathrm{C}}=\right.$ critical pressure $)$ must be achieved. The pressure at the ejector outlet $\left(\mathrm{P}_{6}\right)$ is less than the critical pressure of the condenser $\left(\mathrm{P}_{6} \leq \mathrm{P}_{C}\right)$. In this study, a constant pressure-mixing ejector (CPM Ejector) has been used, where its outlet from the nozzle is in the suction chamber before the fixed chamber. For this ejector type, the primary and secondary flows are mixed in the chamber aspiration at this pressure. The mixing streams pressure remains constant along the chamber from the outlet of the nozzle to the inlet of the constant surface section. This ejector kind has better efficiency than the rest of the ejector [28].

For optimal understanding of the principle of ejector work, it is advisable to familiarize yourself with the gasdynamic lessons and a good understanding of the working principle of convergent-divergent pipes [35, 36].

According to Figure 2, the energy balance at the moment of mixing at the blending point inside the ejector is given by $[23,35]$ :

$$
\left(m_{g}+m_{e}\right) h_{5}=m_{g} \cdot h_{3}+m_{e} \cdot h_{9}
$$

Where "mg, $\mathrm{Kg} / \mathrm{s}$ " is mass flow of primary fluid from generator, "me, $\mathrm{Kg} / \mathrm{s}$ " is mass flow of secondary fluid from evaporator, " $\mathrm{h}_{3}, \mathrm{~kJ} / \mathrm{kg}$ " is the enthalpy of the primary fluid from the generator , " $\mathrm{h}_{5}, \mathrm{~kJ} / \mathrm{kg}$ " is the enthalpy at the mixing point inside of mixing zone and " $\mathrm{h}_{9}, \mathrm{~kJ} / \mathrm{kg}$ " is the enthalpy of secondary fluid from evaporator.

The isentropic efficiency " $\eta_{N}$ " of the ejector nozzle is given by the following equation [23, 35]: 


$$
\eta_{N=} \frac{h_{3}-h_{4}}{h_{3}-h_{4, i s}}
$$

The isentropic efficiency " $\eta_{D}$ " of the ejector diffuser is given by the following relationship [23, 35]:

$$
\eta_{D}=\frac{h_{6, \text { is }}-h_{5}}{h_{6}-h_{5}}
$$

Where " $\mathrm{h}_{4}, \mathrm{~kJ} / \mathrm{kg}$ " is the enthalpy of the primary fluid from the generator expanded through the nozzle, " $\mathrm{h}_{4, \mathrm{is}}, \mathrm{kJ} / \mathrm{kg}$ " is the enthalpy of the primary fluid from the generator expanded isentropically through the nozzle, " $\mathrm{h}_{6}, \mathrm{~kJ} / \mathrm{kg}$ " is the enthalpy of the mixing fluid compressed through the diffuser and " $\mathrm{h}_{6, \mathrm{is}}, \mathrm{kJ} / \mathrm{kg}$ " is the enthalpy of the mixing fluid compressed isentropically through the diffuser.

The ejector mass ratio " $\omega$ " (drive ratio or entrainment ratio) is written as follow [22, 23, 35]:

$$
\omega=\frac{m_{e}}{m_{g}}=\sqrt{\left(\eta_{N} \cdot \eta_{D}\right)\left(\left(h_{3}-h_{4, \mathrm{is}}\right) /\left(h_{6, \mathrm{is}}-h_{5}\right)\right)}-1
$$

As for the isentropic ejector efficiency " $\lambda$ ”, it is given by $[23,35]$ :

$$
\lambda=\eta_{N} \cdot \eta_{D}
$$

The compression ratio " $\mathrm{r}_{\mathrm{p}}$ " is defined by following equation [22, 23, 35]:

$$
r_{p}=P_{c} / P_{e}
$$

The ejector air conditioning subsystem performance "COP ej" is defined as the ratio between the cooling capacity " $\mathrm{Q}_{\mathrm{e}}(\mathrm{W})$ " (from the evaporator) and the required heat input " $\mathrm{Q}_{\mathrm{g}}(\mathrm{W})$ ” (from the generator) to the ejector [20, 22, 23, 35] :

$$
C O P_{e j c}=\frac{Q_{e}}{Q_{g}}=\frac{m_{e}\left(h_{9}-h_{8}\right)}{m_{g}\left(h_{3}-h_{1}\right)}
$$

With " $\mathrm{h}_{1}, \mathrm{~kJ} / \mathrm{kg}$ " is the enthalpy of primary fluid at inlet of the generator and " $\mathrm{h}_{8}, \mathrm{~kJ} / \mathrm{kg}$ " is the enthalpy of secondary fluid at inlet of the evaporator.

Engineering Equation Solver (EES) software has been used as a programming tool to analyze and simplify the energy balance equations of the two loops of the ejector air conditioning subsystem.

\section{Linear Fresnel solar Reflector subsystem}

It is known that the exploiting costs of renewable energies are very high now, so the production costs and the efficiency of the product must be agreed in order to have an efficient device with an acceptable price. For the solar system with parabolic trough solar collectors (PTCs), the PTC designing cost is high compared to LFRs because it relies on the shaping of the glass to obtain the parabolic form of the reflecting mirror [23, 37-39]. On the other hand, the use of flat reflector mirrors will significantly reduce the manufacturing cost of the linear solar reflectors (LFRs) 
[40, 41]. For this reason, much of the scientific research has been directed towards the development the solar systems with the Linear Fresnel solar Reflectors (LFRs), where many countries such as Spain and Germany have widely exploited this technology of acceptable price although its efficiency is low [41], but its thermal performance can be improved by using nanofluids [5, 42-44], because the nanoparticles immersed in pure fluid improve the thermal transfer between the working fluid and the receiver tube [45].

In the literature, many valuable scientific researchers have addressed this type of solar concentrators (LFRs), such as Bellos et al. [25, 41, 43, 46-48], Roostaee and Ameri [49], Pulido-Iparraguirre et al. [50], Marugán-Cruz et al. [51], Barbón et al. [52, 53], Ghodbane et al. [2, 4-7, 54-56] and Moghimi et al. [57, 58]. This collection of valuable scientific research collected all that is related to this type of linear Fresnel solar reflectors (LFRs).

The operating principle of a Linear Fresnel Reflector (LFR) lies in its flat mirrors, where each of these mirrors can be rotated following the path of the sun to constantly redirect and focus the direct sunlight "DNI, W/m²" towards an absorber tube. A heat transfer fluid is heated by circulating in this horizontal tube [41]. As for the absorber tube, it is coated with a special black selective layer, and surrounded by a glass tube in order to reduce heat loss with the ambient air.

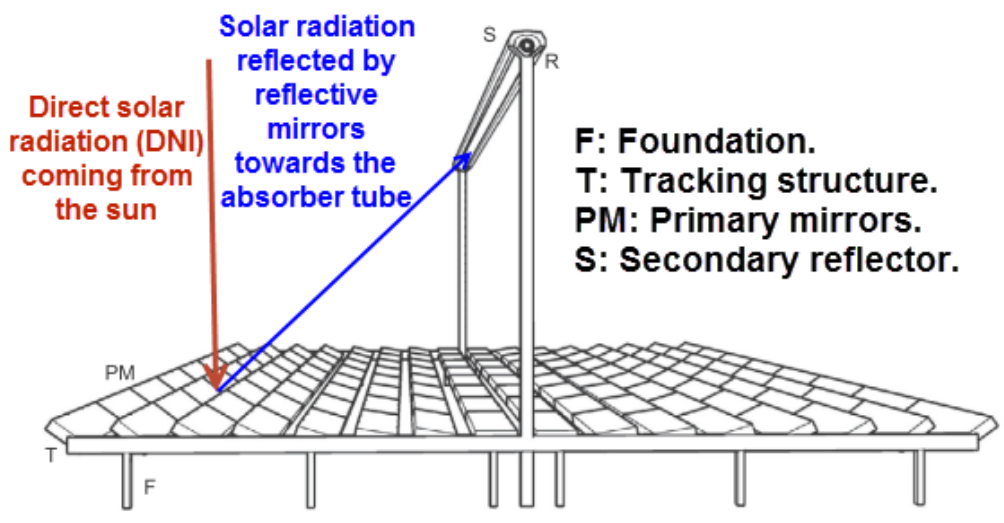

Figure 3. Schematic of a linear Fresnel solar reflector (LFR) [51]

In this part of the study, attention will be paid to the numerical simulation of the energy balance of the copper absorber tube. Therefore, optical efficiency " $\eta_{\mathrm{op}}$ ", thermal efficiency " $\eta_{\mathrm{t}}$ ”, copper absorber tube temperature " $\mathrm{T}_{\mathrm{Ab}}, \mathrm{K}$ ”, heat transfer fluid temperature " $\mathrm{T}_{\mathrm{HTF}}, \mathrm{K}$ " at the exit of the absorber tube, glass tube temperature " $\mathrm{T}_{\mathrm{G}}, \mathrm{K}$ " and global heat loss coefficient " $\mathrm{U}_{\mathrm{L}}, \mathrm{W} / \mathrm{m}^{2} \mathrm{~K}$ " will be determined. Table 1 shows the geometric parameters of the linear Fresnel solar reflector, while the table 2 shows the optical characteristics.

Table 1 . Geometrical parameters of the LFR concentrator

\begin{tabular}{|c|c|}
\hline Geometric characteristics & Value \\
\hline Outside diameter of the copper absorber tube $\left(\mathrm{D}_{\mathrm{A}, \mathrm{o}}\right)$ & $0.022 \mathrm{~m}$ \\
\hline Inner diameter of the copper absorber tube $(\mathrm{DA}, \mathrm{i})$ & $0.020 \mathrm{~m}$ \\
\hline Outer diameter of the glass cover $\left(\mathrm{D}_{\mathrm{G}, \mathrm{o}}\right)$ & $0.026 \mathrm{~m}$ \\
\hline Inside diameter of the glass cover $\left(\mathrm{D}_{\mathrm{G}, \mathrm{i}}\right)$ & $0.0235 \mathrm{~m}$ \\
\hline Mirror length $(\mathrm{L})$ & $12.27 \mathrm{~m}$ \\
\hline Mirror width $(\mathrm{l})$ & $1.1 \mathrm{~m}$ \\
\hline Focal distance $(\mathrm{F})$ & $1.3 \mathrm{~m}$ \\
\hline
\end{tabular}


Figure 1 illustrate the energy balance of the copper absorber tube. LFR performances have been analyzed by a numerical tool as a function of the climatic conditions (direct normal irradiance "DNI, W/m"', Wind speed " $W_{S}$, $\mathrm{m} / \mathrm{s}$ " and ambient air temperature " $\mathrm{T}_{\mathrm{amb}}, \mathrm{K}$ ”) for the El-Oued site "Oued Souf" (altitude $61 \mathrm{~m}$, latitude $33.51^{\circ} \mathrm{N}$ and longitude $\left.6.78^{\circ} \mathrm{E}\right)$, Algeria.

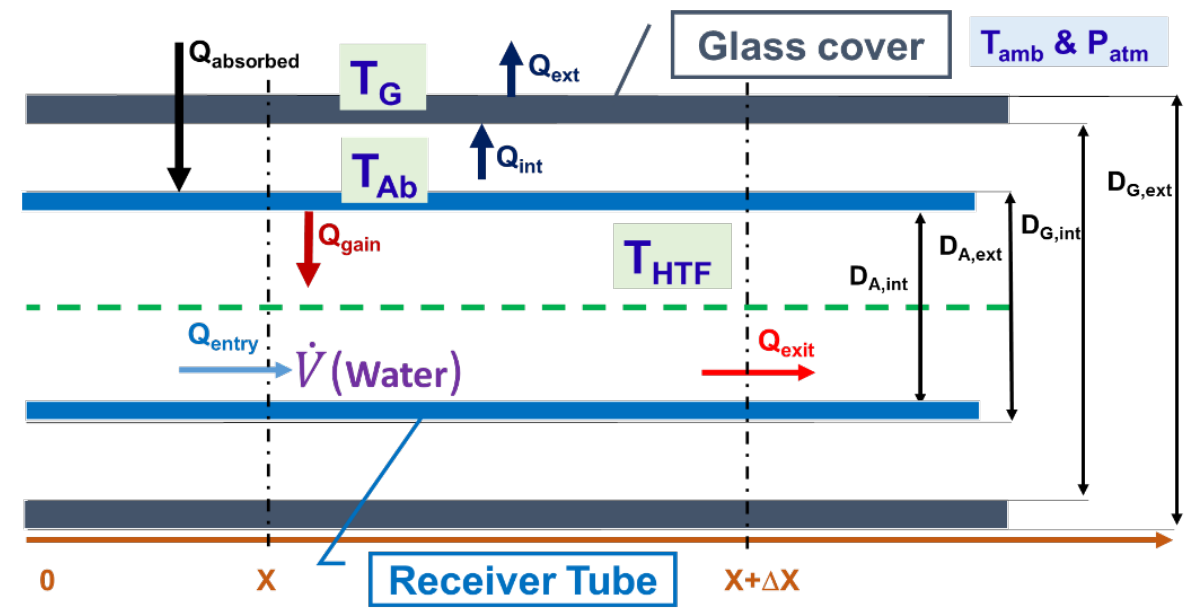

Figure 4. The energy balance at the absorber tube

Heat exchange occurs between the heat transfer fluid, the copper absorber tube and the glass cover. A control program in Engineering Equation Solver (EES) software has been developed to make the necessary calculations. To facilitate calculation and further explanation of thermal behavior of the energy balance, these hypotheses have been adopted:

- The heat transfer fluid is incompressible (in this study, Water (R718) has been used as heat transfer fluid);

- The ambient air temperature " $\mathrm{T}_{\mathrm{amb}}, \mathrm{K}$ " around the concentrator is uniform;

- The shadow effect of the absorber tube on the mirror is negligible;

- The solar flux at the absorber is evenly distributed;

- The glass cover is considered opaque to infrared radiation;

- The conduction exchanges in the absorber tube and the glass tube are negligible.

Table 2. Optical parameters of the studied solar reflector

\begin{tabular}{|c|c|}
\hline Properties & Value \\
\hline Absorber tube absorptivity “ $\alpha$ ” & 0.8 \\
\hline Absorber tube emissivity " $\varepsilon_{\mathrm{Ab}}$ " & 0.12 \\
\hline Cover glass transmittance “ $\tau$ ” & 0.945 \\
\hline Emissivity of glass Cover " $\varepsilon_{\mathrm{G}}$ " & 0.935 \\
\hline External cover emissivity " $\varepsilon_{\text {ex-c }}$ " & 0.5 \\
\hline Overall average optical error " $\mathrm{O}_{\text {perror" }}$ & $03 \mathrm{mrad}$ \\
\hline Primary mirrors reflectivity " $\rho_{\mathrm{m}}$ " & 0.85 \\
\hline Secondary mirrors reflectivity " $\rho_{\mathrm{sm}}$ " & 0.95 \\
\hline Secondary reflector emissivity " $\varepsilon_{\mathrm{sr}}$ " & 0.2 \\
\hline
\end{tabular}

The heat flux “Qgain, W" transmitted to the fluid is given by the following relation $[1,59]$ :

$$
Q_{\text {gain }}=F_{r}\left[\eta_{\mathrm{op}} \times \mathrm{DNI} \times \mathrm{A}_{a}-U_{L} \times A_{r} \times\left(T_{i}-T_{\mathrm{amb}}\right)\right]
$$


With " $A_{a}, m^{2}$ " is the opening area of the solar collector, "Ar, $\mathrm{m}^{2}$ " is the copper absorber tube surface, "T $\mathrm{T}$, (K) "is the fluid inlet temperature, and Fr is the heat dissipation factor.

The optical efficiency “ " $\eta_{\text {opt }}$ " of the LFRs solar reflectors is given by following equation [60, 61]:

$$
\eta_{\mathrm{opt}}=\alpha \times \rho_{m} \times \tau \times \gamma \times K_{t}\left(\theta_{t}\right) \times K_{l}\left(\theta_{l}\right)
$$

With " $\gamma$ ” is the intercept factor, $K_{l}\left(\theta_{l}\right)$ is the correction factors of incidence angle in the longitudinal plane and $K_{t}\left(\theta_{t}\right)$ is the correction factors of incidence angle in the transverse plane. To calculate the correction factors $K_{l}\left(\theta_{l}\right)$ and $K_{t}\left(\theta_{t}\right)$, the following equations were used [51, 62]:

$$
\begin{gathered}
K_{l}\left(\theta_{l}\right)=1.0031-0.2259 \times \theta_{l}+0.5368 \times \theta_{l}^{2}-1.6434 \times \theta_{l}^{3}+0.722 \times \theta_{l}{ }^{4} \\
K_{t}\left(\theta_{t}\right)=0.9896+0.044 \times \theta_{t}-0.0721 \times \theta_{t}{ }^{2}-0.2327 \times \theta_{t}{ }^{3}
\end{gathered}
$$

The overall heat loss coefficient " $\mathrm{U}_{\mathrm{L}}, \mathrm{W} / \mathrm{m}^{2} \mathrm{~K}$ " is given as follows $[1,59]$ :

$$
U_{L}=\left[\frac{A_{\mathrm{Ab}, \mathrm{ext}}}{\left(h_{w}+h_{\mathrm{r}, \mathrm{c}-a}\right) A_{\mathrm{G}, \mathrm{ext}}}+\frac{1}{h_{\mathrm{r}, \mathrm{r}-a}}\right]^{-1}
$$

Where " $\mathrm{A}_{\mathrm{Ab} \text {,ext }}, \mathrm{m}^{2 "}$ is the extern surface of the copper absorber tube, "A,ext, $\mathrm{m}^{2 "}$ is the extern surface of the glass cover, "hw, W/m² $\mathrm{K}$ " is the convective heat exchange coefficient between the glass cover and the ambient air, "hr,ca, $\mathrm{W} / \mathrm{m}^{-2} \cdot \mathrm{K}$ " is the radiative exchange coefficient between the glass cover and the ambient air and "hr,ra, $\mathrm{W} / \mathrm{m}^{-2} \cdot \mathrm{K}$ " is the radiative exchange coefficient between the copper absorber tube and the glass cover.

To calculate the heat transfer fluid temperature " $\mathrm{T}_{\mathrm{HTF}}, \mathrm{K}$ " at the exit of the absorber tube, the following equation has been used [25, 34, 39]:

$$
T_{o}=T_{i}+\frac{Q_{\text {gain }}}{\dot{m} \mathrm{C}_{p}}
$$

The thermal efficiency of the LFRs solar concentrators can be calculated by the equation:

$$
\eta_{\mathrm{th}}=\eta_{\mathrm{opt}}-\frac{U_{L} \times A_{\mathrm{A}, \mathrm{ext}} \times\left(T_{\mathrm{Ab}}-T_{\mathrm{amb}}\right)}{\mathrm{DNI} \times A_{a}}
$$

Therefore, these equations (from 8 to 14) have summarized the behavior of the energy balance at the level of the absorbent tube. As previously mentioned, Water is the heat transfer fluid in the solar subsystem. Engineering Equation Solver (EES) software has been used as a programming language. These equations will be simplified and analyzed using numerical methods.

\section{DYNAMIC STUDY OF THE EJECTOR SOLAR AIR CONDITIONING SYSTEM}

Ejectors are static tools designed to compress, aspirate or mix gases, vapors, liquids and sometimes solids through the expansion of the driving fluid (primary fluid or working fluid). The main benefit that the ejector provides to a refrigerating machine is instead of using electrical energy, it uses free thermal energies such as solar energy. In this study, a supersonic ejector was used, where this device is a very simple mechanical system with no moving parts, so it does not require repairs or expensive maintenance.

An ejector solar air conditioning machine is a system that has three sources of heat (a hot source corresponding to the motive heat supplied to the system, a cold source corresponding to that of the production of cold and a warm source that makes a connection between both sources). The ejector solar air conditioner is similar to the conventional compression air conditioning system except that a pump, a steam generator and an ejector replace the compressor. This modern and eco-friendly air conditioner features these advantages: 
- It is very simple for manufacturing;

- The ejector air conditioning system is a machine that allows the use of clean refrigerants, where the refrigerants used do not cause pollution to the environment;

- The refrigeration system can operate at very low-pressure levels which allows the use of new refrigerants such as water, as has been done in this study;

- It has great safety measure during use.

Figure 5 illustrates the complete principle of an air-conditioning system that relies on solar energy. The direct normal irradiance (DNI) transformed by the linear Fresnel solar concentrator (LFR) into thermal energy, where this thermal energy is used to generate the high temperature and high-pressure steam (primary fluid) in the generator, which expands in the primary nozzle of the ejector.

At the outlet, the high speed of the primary fluid drives the secondary fluid from the evaporator. Then, the primary and secondary streams mix at constant pressure in the mixing chamber. At the mixing chamber level, the first pressure increase due to the formation of a shock wave takes place in the mixing chamber followed by the second due to compression in the Diffuser. At the outlet of the Diffuser, the mixture condenses in a condenser. After that, a part of the condensate passes into the evaporator through a throttle valve to produce the cooling effect while the rest of the liquid returns to the generator via a circulation pump.

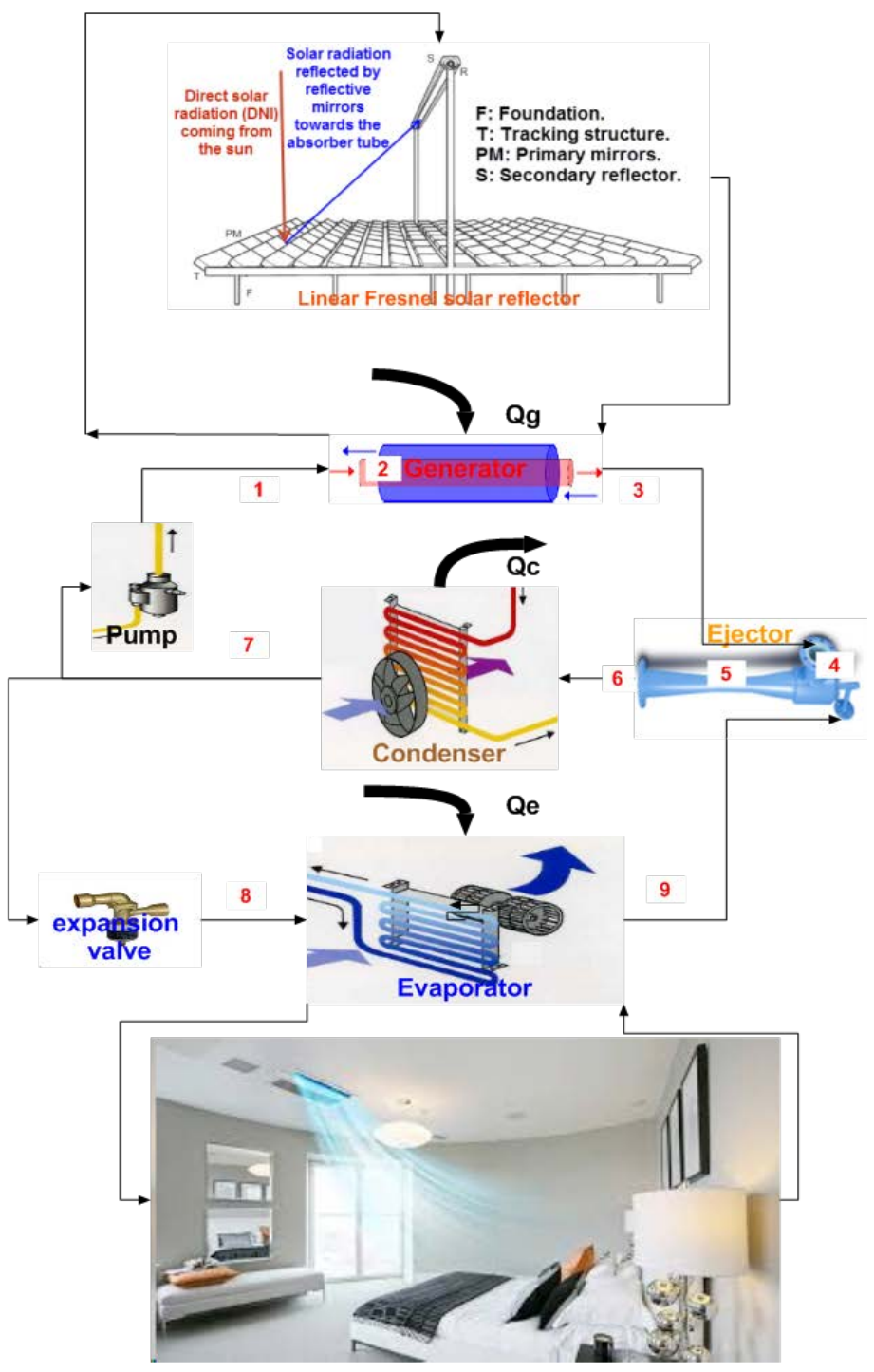

Figure 5. Solar ejector air conditioning system for balance analysis 
As shown in equation (15), the ejector solar air conditioning machine performance, it can be introduced as the product of the ejector air conditioning subsystem performance (COPejc) and the thermal efficiency ( $\eta$ th) of used solar reflector. On the other hand, this performance is called the system thermal ratio (STR). Therefore, the STR ratio is given by $[20,22]$ :

$$
S T R=C O P_{e j c} \times \cdot \eta_{t h}
$$

The air conditioning system studied in this scientific work can provide a cooling load of $12.5 \mathrm{~kW}$. The main purpose of this study is to determine the parameters that are affected on the various performance of the ejector solar air conditioning system. In this paper, the thermal model of the linear Fresnel solar concentrator is without storage tank and without auxiliary boiler. The simulation is executed under the following assumptions:

- In order to eliminate the analytical error induced by the consideration that the working fluid (refrigerant) that passes through the ejector is a perfect fluid;

- The fact thermodynamic properties of the refrigerant (Water "R718”) were used in this study;

- $\quad$ The kinetic energy of primary and secondary flows is negligible;

- $\quad$ The flow is stationary;

- $\quad$ The internal walls of the ejector are adiabatic;

- The outlet of the ejector is connected to the condenser.

Generally, the STR of ejector solar air conditioning machine depends directly on the refrigerant used. Water (R718) is a broker a refrigerant wet. For this type of refrigerant, small droplets of refrigerant can be formed and damage the primary nozzle, but this imbalance can be overcome by optimizing the practical conditions of the machine, which is what has been achieved in this study.

\section{RESULTS AND DISCUSSION}

\section{Climatic condition}

Climate conditions (Direct-normal irradiation "DNI, W/m", Wind speed "W $\mathrm{S}, \mathrm{m} / \mathrm{s}$ " and ambient air temperature “ $\mathrm{T}_{\mathrm{amb}}, \mathrm{K}$ ”) are an important element that has a direct and severe impact on the system thermal ratio (STR) of the studied air conditioner.

To calculate the direct-normal irradiation "DNI, W/m" from sunrise to sunset, an algorithm has been developed to simulate it by the semi-empirical model of PERRIN DE BRICHAMBAUT [3, 36], where the July 17, 2018 was selected as the typical day of the study. Figure 6 clearly illustrates the changes of the direct-normal irradiation "DNI, W/m" on July 17, 2018.

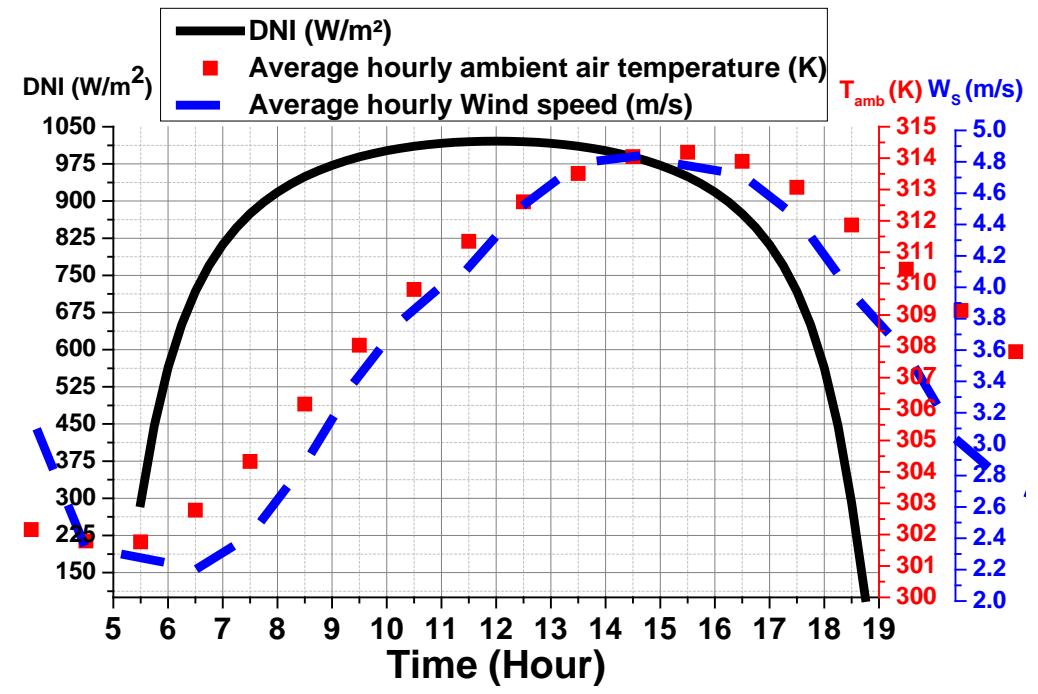

Figure 6. Change in weather conditions for July 18, 2018 
The climate condition of El-Oued region is desert. Through data from meteorological stations available on the Internet [63], there is virtually no rainfall all year long in El Oued, where the average annual rainfall is $74 \mathrm{~mm}$, resulting in a virtually dry atmosphere throughout the year. In addition, the hottest month of the year is July, but the coldest month is January, where the difference in air temperature between the lowest and the highest is equal to 295.75 $\mathrm{K}$ throughout the year.

As shown in Figure 6, the maximum value of direct normal irradiance has peaked at midday, with a value equal to $1021\left(\mathrm{~W} / \mathrm{m}^{2}\right)$. Generally, the average solar radiation change for the studied day has exceeded $800\left(\mathrm{~W} / \mathrm{m}^{2}\right)$ from $07 \mathrm{H} 00$ to $17 \mathrm{H} 00$. These values for solar radiation are very significant and can be exploited to operate an air conditioning system.

\section{Assessment of the efficiency of the solar system}

The linear Fresnel solar reflector (LFR) is a device designed to collect solar energy transmitted by direct normal irradiance and communicate it to a heat transfer fluid (gas or liquid) in the form of heat. This heat energy can then be used in various industrial processes. The nature of heat transfer fluids is one of the most important factors affecting the efficiency of the associated work system. A heat transfer fluid (HTF) is a fluid that transports heat between two or more temperature sources. These fluids are used in thermal engine cooling systems such as car engines, refrigerators, air conditioners, solar thermal collectors, electronic circuit radiators, coal, oil, gas or nuclear power plants. Each heat transfer fluid is chosen according to its physical and chemical properties as: the viscosity, the volume heat capacity, the latent heat of vaporization (or liquefaction) in case of phase change, the electrical conductivity, the oxidizing properties, etc. In addition, the effects of the heat transfer fluid (HTF) on the environment and its cost must be taken into account, because they are important factors in selecting the practical conditions of the system.

In this study, Water has been adopted as heat transfer fluid. Figure 7 shows changes in the temperature of the copper absorber tube " $\mathrm{T}_{\mathrm{Ab}}, \mathrm{K}$ ”, the heat transfer fluid " $\mathrm{T}_{\mathrm{HTF}}, \mathrm{K}$ ” and the glass cover " $\mathrm{T}_{\mathrm{G}}, \mathrm{K}$ ”.

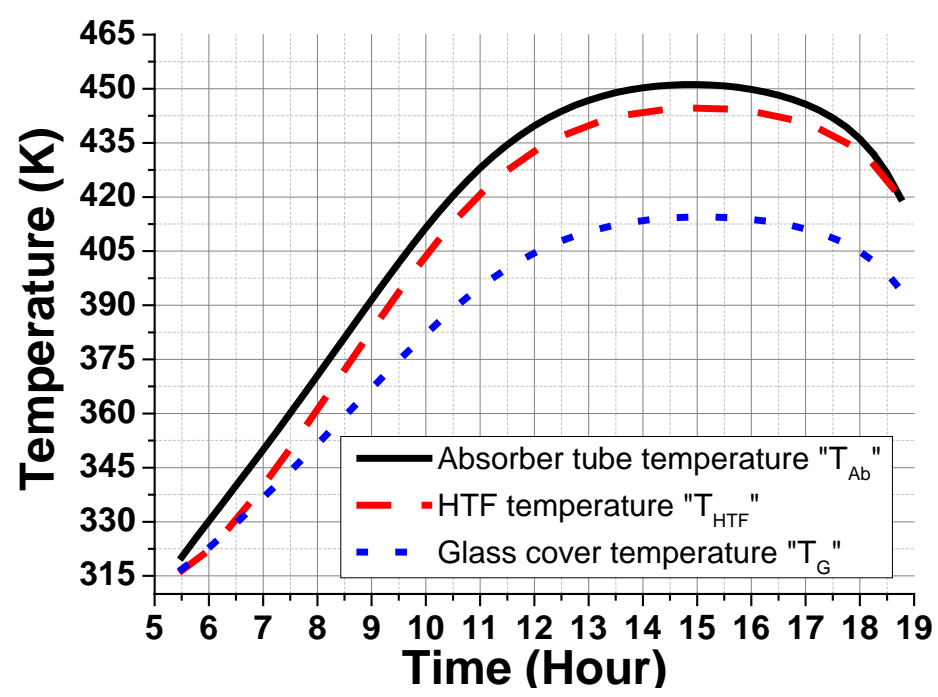

Figure 7. Variations of temperatures on July 17, 2018

Through the figure 7, it was observed that the temperature of the heat transfer fluid (HTF) has reached 444.60 $(\mathrm{K})$, which indicates that the water has changed from its liquid state to the vapor state. The copper absorber tube temperature has reached $450(\mathrm{~K})$ and the glass cover temperature has reached $415(\mathrm{~K})$. It should be noted that the climatic factors have a direct impact on the amount of heat gained by the heat transfer fluid from the absorber tube.

The convective and radiative exchange losses to the outside air are very important, in order to limit them, a glass envelope covers the copper absorber tube and makes it possible, by evacuating the annular space, to eliminate thermal losses by convection between the absorber tube and the glass cover. In addition, the heat losses can be reduced also by reducing the emissivity in the infrared of the absorber tube using the suitable selective surfaces. These surfaces are dark in color to absorb the maximum amount of solar radiation by emitting very little infrared. In this study, the 
absorber tube is a copper tube covered with a suitable selective layer and surrounded by a glass cover. With regard to air temperature, it influences the total coefficient of heat loss by convection outdoors, because the physical properties of exterior air vary according to the ambient temperature. Therefore, a small emissivity of the absorber tube and the vacuum in the annular space between the absorber tube and the glass cover can reduce heat losses. It can be said that the internal thermal radiation losses decrease with the reduction of the absorber tube emissivity and the convective losses decrease with the creation of the vacuum in the annular space. Figure 8 shows the changes in the total coefficient of heat losses " $\mathrm{U}_{\mathrm{L}}, \mathrm{W} / \mathrm{m}^{2} \mathrm{~K}$ " at the absorber tube level.

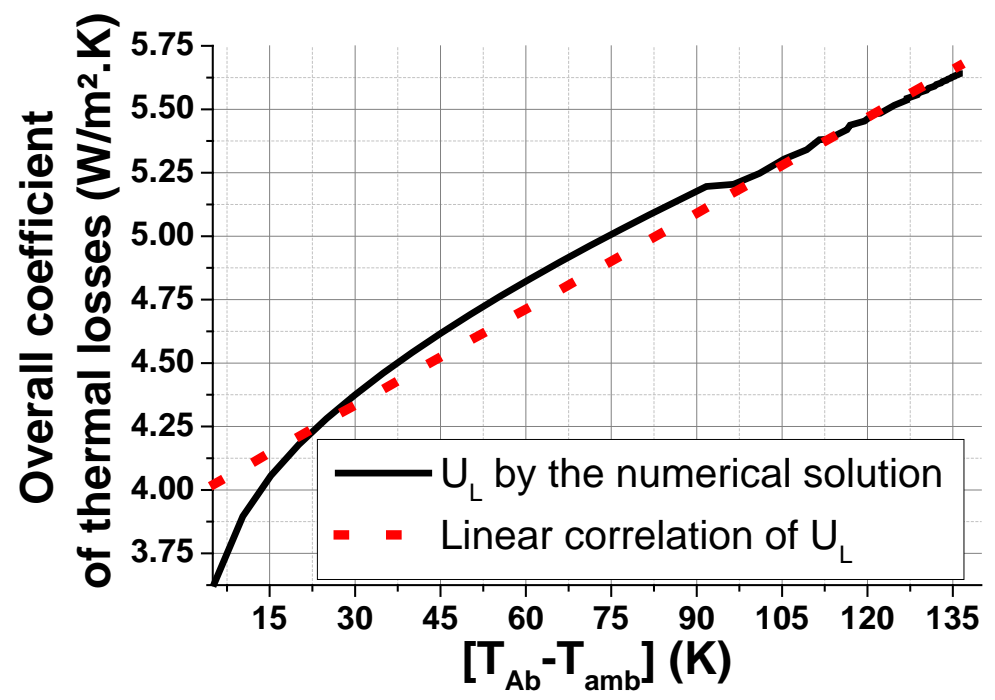

Figure 8. Variation of the overall coefficient of thermal losses

Generally, the efficiency measurement of the linear Fresnel solar concentrator is the ratio between the thermal power that it provides to the heat transfer fluid and the power of the direct solar radiation, which arrives on the useful surface of this collector. The power supplied is the power converted to heat in the solar concentrator, minus the losses. The thermal losses are the infrared radiation returned to the outside and the heat dissipated to the outside. As shown in Figure 8, the change in the total thermal loss coefficient " $\mathrm{U}_{\mathrm{L}}, \mathrm{W} / \mathrm{m}^{2} \mathrm{~K}$ " is an almost linear function that increases with the increasing temperature difference between the absorber tube and the surrounding atmosphere. The geometric dimensions of the solar collector and the climatic conditions of the site in which it is located directly affect this coefficient. Equation of the linear correlation of total coefficient of heat losses " $\mathrm{U}_{\mathrm{L}}, \mathrm{W} / \mathrm{m}^{2} \mathrm{~K}$ " with $\mathrm{R}^{2}=0.97646$ is given by:

$$
U_{L}=3.9571+0.01259\left(T_{A b}-T_{a m b}\right)
$$

\section{Performance evaluate of the ejector solar air conditioning machine}

The ejector solar air conditioning machine modeling is essentially dependent on the geometry of the ejector and the thermodynamic state of the refrigerants flowing through it. The equations of the machine's operating model are based on the principles of mass conservation, momentum conservation, and energy conservation. Based on the fulfillment of the above requirement of the mixing fluid pressure $\left(\mathrm{P}_{6}\right)$ at the outlet of the Diffuser and going to the condenser $\left(\mathrm{P}_{\mathrm{c}}\right)$, where it must be the pressure at the ejector outlet $\left(\mathrm{P}_{6}\right)$ is less than the critical pressure of the condenser $\left(\mathrm{P}_{6} \leq \mathrm{P}_{\mathrm{C}}\right)$. From this condition, the rest of the geometric parameters of the ejector such as the primary nozzle throat diameter $\left(D_{t}\right)$ and the constant area section diameter $\left(D_{m}\right)$ has been determined. After this step, the thermodynamic parameters (drive ratio “ $\omega$ ”, ejector air conditioning subsystem performance "COPejc" and system thermal ratio "STR") has been calculated. Table 3 translate the operating conditions of the ejector air conditioning subsystem, while the figure 9 shows the thermodynamic loops of the solar air conditioner that depends on the ejector. As a reminder, it is hereby noted that:

- In the linear Fresnel solar reflector subsystem, the Water has been used as a heat transfer fluid (HTF);

- In the linear ejector air conditioning subsystem, the Water (R718) has been used as a refrigerant. 
Journal of Thermal Engineering, Research Article, Vol. 7, No. 1, pp. 172-189, January, 2021

Table 3 . Service operating conditions of the ejector solar air conditioning machine

\begin{tabular}{|l|c|}
\hline Service operating conditions & Value \\
\hline Generator temperature $\left(\mathrm{T}_{\mathrm{g}}\right)$ & $373.15 \mathrm{~K}\left(100^{\circ} \mathrm{C}\right)$ \\
\hline Condenser temperature $\left(\mathrm{T}_{\mathrm{c}}\right)$ & $305.15 \mathrm{~K}\left(32.5^{\circ} \mathrm{C}\right)$ \\
\hline Evaporator temperature $\left(\mathrm{T}_{\mathrm{e}}\right)$ & $283.15 \mathrm{~K}\left(10^{\circ} \mathrm{C}\right)$ \\
\hline
\end{tabular}

In order to have an idea about the behavior and the evolution of the thermodynamic parameters of the refrigerant during its passage inside in the loops of the solar ejector air conditioner (evolutions of the temperature "K", the pressure "Pa" and the enthalpy “J/kg"), Figure 9 has been plotted (P-h).

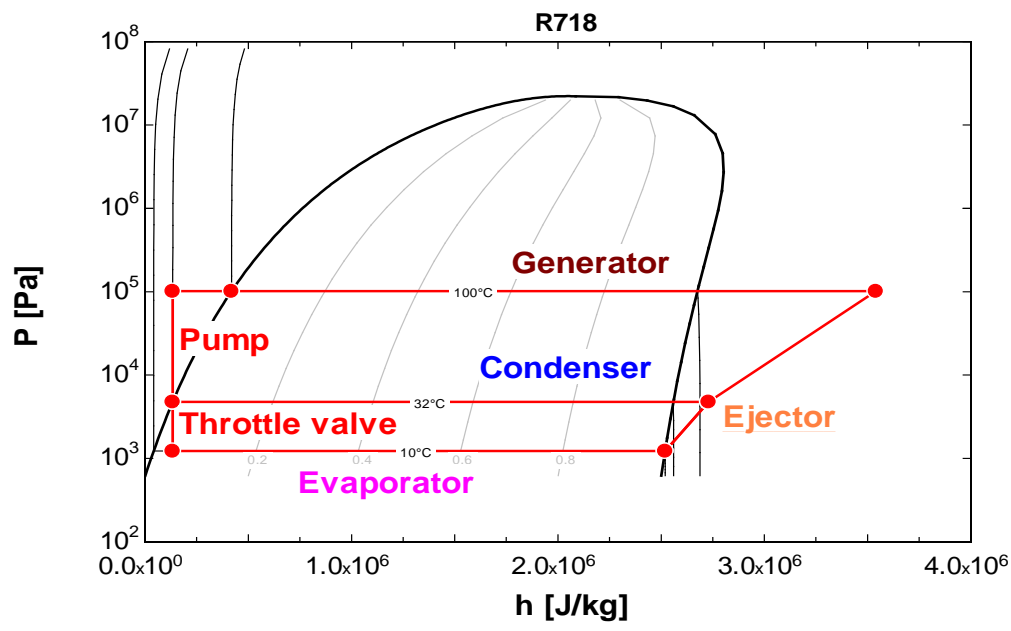

Figure 9. (P-h) curve changes for solar air conditioner with ejector

Table 4 shows the dimensions of primary nozzle throat diameter $\left(D_{t}\right)$ and constant area section diameter $\left(D_{m}\right)$ which is characterized by the ejector under critical conditions $\left(\mathrm{P}_{6} \leq \mathrm{P}_{c}\right.$, where $\mathrm{Pc}_{c}=4758$ Pascal $)$ with the previous operating conditions (see Table 3 ) and with a cooling load equal to $12.5 \mathrm{~kW}$.

Table 4 . Dimensions of $\left(\mathrm{D}_{\mathrm{t}}\right)$ and $\left(\mathrm{D}_{\mathrm{m}}\right)$ under critical conditions

\begin{tabular}{|l|l|c|}
\hline \multirow{2}{*}{ Ejector critical condition $\left(\mathbf{P}_{\mathbf{6}} \leq \mathbf{P c}=\mathbf{4 7 5 8}\right.$ Pascal) } & Primary nozzle throat diameter $\left(\mathrm{D}_{\mathrm{t}}\right)$ & $0.006009 \mathrm{~m}$ \\
\cline { 2 - 3 } & Constant area section diameter $\left(\mathrm{D}_{\mathrm{m}}\right)$ & $0.04479 \mathrm{~m}$ \\
\hline
\end{tabular}

Table 5 shows the value of the drive ratio " $\omega$ " and the performance value of the ejector air conditioning subsystem "COPejc” with a cooling load "Q" equal to $12.5 \mathrm{KW}$.

Table 5 . Drive ratio and performance of the ejector cooling subsystem with a cooling load of $12.5 \mathrm{KW}$

\begin{tabular}{|c|c|c|}
\hline \multirow[b]{2}{*}{$\begin{array}{l}\text { Ejector critical condition }\left(\mathrm{P}_{6} \leq \mathrm{Pc}=4758\right. \\
\text { Pascal) }\end{array}$} & drive ratio " $\omega "$ & 0.4934 \\
\hline & $\begin{array}{c}\text { performance value of the ejector air conditioning } \\
\text { subsystem "COP }{ }_{\text {ejc }}\end{array}$ & 0.60664 \\
\hline
\end{tabular}

Figure 10 illustrates the evolution of the system thermal ratio "STR" of air conditioning system in critical mode, and thermal efficiency curve changes of the LFR solar concentrator as a function of time during the day of July 17, 2018. 


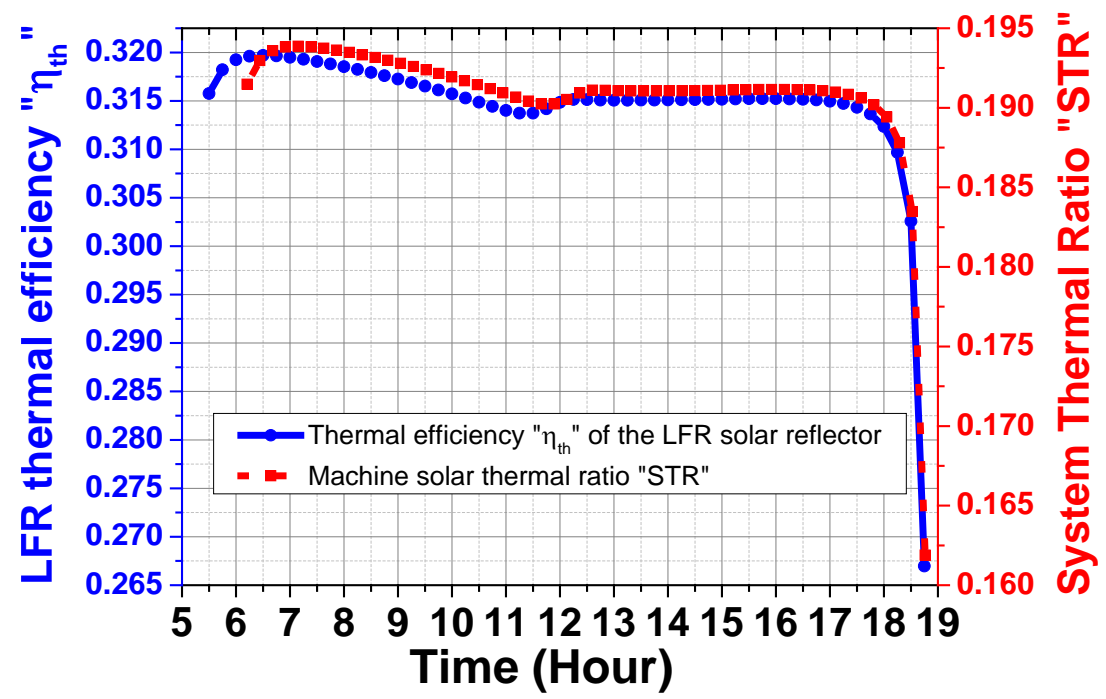

Figure 10. Change in LFR thermal efficiency and STR

From Figure 10, it is very remarkable that the "STR" varies automatically according to the temperatures " $\mathrm{T}_{\mathrm{e}}$, $K$ ", " $T_{c}, K$ ", and " $T_{g}, K$ " of the ejector air conditioning subsystem, and is affected by the change of the thermal efficiency of the linear Fresnel solar collector. It seems clear as well as the average performance of the machine is about $19.17 \%$. It can be said that this performance value "STR" is generally acceptable since the average thermal efficiency " $\eta$ th" of the Linear Fresnel solar concentrator is equal to $31.60 \%$.

Finally, the application of this type of air conditioner shows that the "STR" is very sensitive to changes of the condenser temperature " $T_{c}, K$ ", where the high temperature of the condenser reduces the performance " $C O P_{\text {ejc }}$ " of the air conditioner subsystem with the ejector. The increasing the temperature of generator " $\mathrm{T}_{\mathrm{g}}, \mathrm{K}$ " and evaporator " $\mathrm{T}_{\mathrm{e}}, \mathrm{K}$ " increases the performance " $\mathrm{COP}_{\mathrm{ejc}}$ " of the air conditioner subsystem with the ejector.

\section{CONCLUSION}

The scientific work that it has been presented in this paper has allowed us to acquire very important knowledge about ejector solar air conditioning machines.

In this study, the cooling load of the solar air conditioner connected with a supersonic ejector is $12.5 \mathrm{~kW}$. Through numerical simulations, the performance of the air conditioning subsystem " $\mathrm{COP}_{\mathrm{ejc}}$ " is very sensitive to changes of the condenser temperature " $\mathrm{T}_{\mathrm{c}}, \mathrm{K}$ ", so to increase the performance of the machine it is necessary to increase the temperatures of the hot sources (" $\mathrm{T}_{\mathrm{g}}, \mathrm{K}$ ", and " $\mathrm{T}_{\mathrm{e}}, \mathrm{K}$ "). On the other hand, it is found that the Fresnel linear concentrator is effective to operate this machine, even if it has a low thermal efficiency.

In addition, the average thermal efficiency " $\eta$ th" of the studied solar reflector reached $31.60 \%$, while the average value of the total coefficient of heat losses " $\mathrm{U}_{\mathrm{L}}, \mathrm{W} / \mathrm{m}^{2} \mathrm{~K}$ " at the absorber tube level is $5.19 \mathrm{~W} / \mathrm{m}^{2} \mathrm{~K}$.

As the average value of the system thermal ratio "STR" of air conditioning machine in critical mode is 19.17 $\%$ with a drive ratio " $\omega$ " equals 0.4934 and "COP ejc" equals 0.60664 .

In the end, this technique can be exploited in the Algerian desert, where the fossil energies are extracted and exploited. This technology will reduce the consumption of electric power in these institutions in large proportions.

As tomorrow's perspective, there is a serious effort by the research team to transform this numerical work into an experimental work, in order to improve the operational conditions of this type of systems.

\section{NOMENCLATURE}

$A_{a} \quad$ Opening area of the solar collector, $\mathrm{m}^{2}$

$A_{A b, e x t} \quad$ Extern surface of the copper absorber tube, $\mathrm{m}^{2}$

$A_{G, \text { ext }} \quad$ Extern surface of the glass cover, $\mathrm{m}^{2}$ 


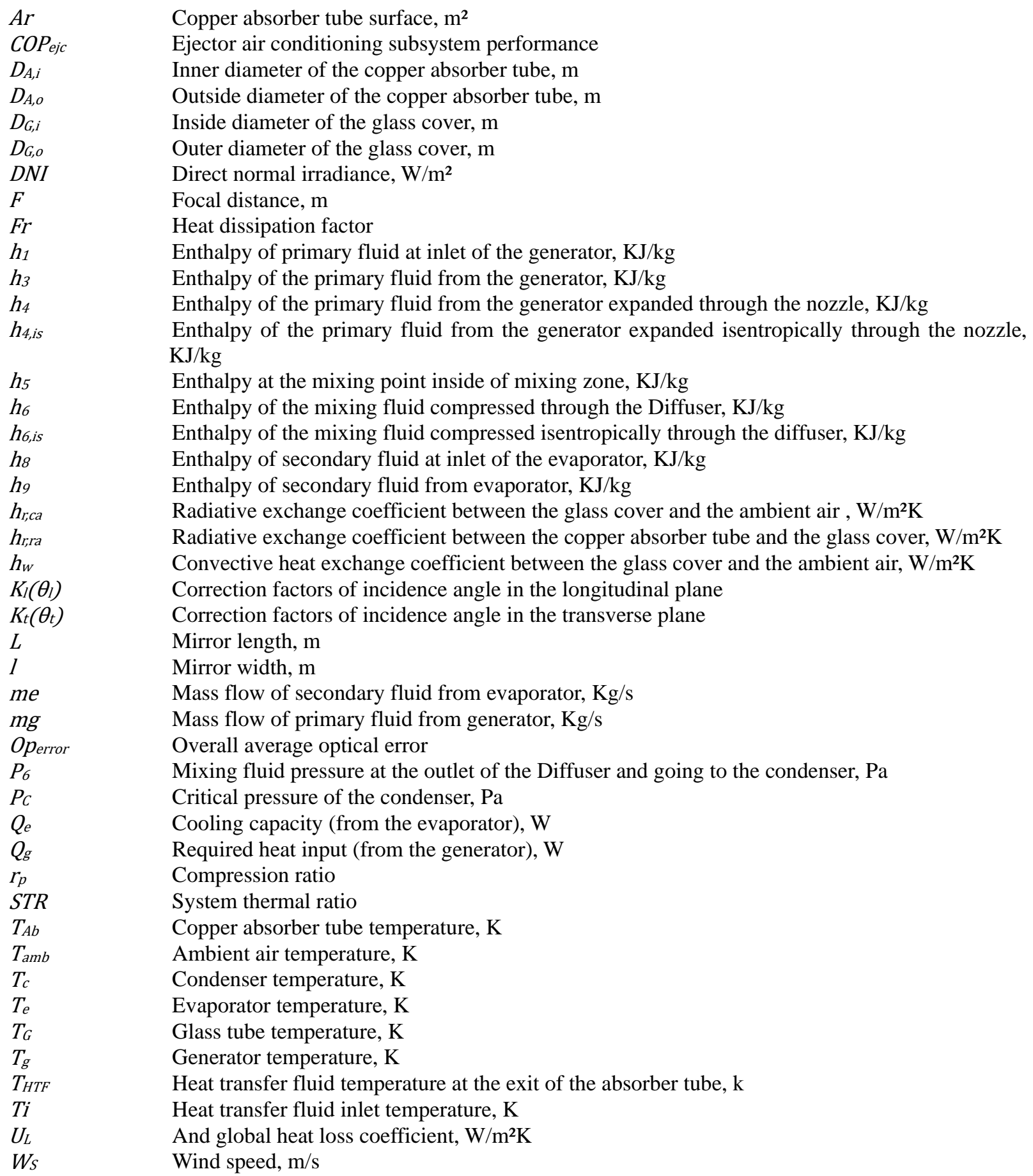

Greek symbols

$\tau$
$\gamma$
$\varepsilon_{A b}$
$\varepsilon_{G}$
$\varepsilon_{S T}$
$\varepsilon_{e x-c}$
$\alpha$
$\eta_{o p}$

Cover glass transmittance

Intercept factor

Absorber tube emissivity

Emissivity of glass Cover

Secondary reflector emissivity

External cover emissivity

Absorber tube absorptivity

Optical efficiency 
Journal of Thermal Engineering, Research Article, Vol. 7, No. 1, pp. 172-189, January, 2021

$\begin{array}{ll}\eta_{t h} & \text { Thermal efficiency } \\ \lambda & \text { Isentropic ejector efficiency } \\ \rho_{m} & \text { Primary mirrors reflectivity } \\ \rho_{s m} & \text { Secondary mirrors reflectivity } \\ \omega & \text { Drive ratio or entrainment ratio }\end{array}$

\section{REFERENCES}

[1] Kalogirou S A, Solar Energy Engineering : Processes and Systems. 1st ed. Academic Press; 2009.

[2] Ghodbane M, Boumeddane B, Said N. A linear Fresnel reflector as a solar system for heating water: theoretical and experimental study. Case Studies in Thermal Engineering 2016; 8(C): 176-186. http://dx.doi.org/10.1016/j.csite.2016.06.006.

[3] Ghodbane M, Boumeddane B, Moummi N, Largot S, Berkane H. Study and numerical simulation of solar system for air heating. Journal of Fundamental and Applied Sciences 2016; 8(1): 41- 60. http://dx.doi.org/10.4314/jfas.v8i1.3.

[4] Rahman S, Issa S, Said Z, El Haj Assad M, Zadeh R, Barani Y. Performance enhancement of a solar powered air conditioning system using passive techniques and SWCNT /R-407c nano refrigerant. Case Studies in Thermal Engineering 2019; 16: 100565. https://doi.org/10.1016/j.csite.2019.100565.

[5] Ghodbane M, Said Z, Hachicha AA, Boumeddane B. Performance assessment of linear Fresnel solar reflector using MWCNTs/DW nanofluids. Renewable Energy 2020; 151: 43-56. https://doi.org/10.1016/j.renene.2019.10.137.

[6] Ghodbane M, Boumeddane B, Said N. Design and experimental study of a solar system for heating water utilizing a linear Fresnel reflector. Journal of Fundamental and Applied Sciences 2016; 8(3): 804-825. http://dx.doi.org/10.4314/jfas.v8i3.8.

[7] Ghodbane M, Bellos E, Said Z, Boumeddane B, Hussein AK, Kolsi L. Evaluating energy efficiency and economic effect of heat transfer in copper tube for small solar linear Fresnel reflector. Journal of Thermal Analysis and Calorimetry 2020. https://doi.org/10.1007/s10973-020-09384-6.

[8] Mosleh HJ, Hakkaki-Fard A, DaqiqShirazi M. A year-round dynamic simulation of a solar combined, ejector cooling, heating and power generation system. Applied Thermal Engineering 2019. https://doi.org/10.1016/j.applthermaleng.2019.02.114.

[9] Bellos E, Tzivanidis C, Antonopoulos KA. Parametric investigation and optimization of an innovative trigeneration system. Energy Conversion and Management 2016; 127: 515-525. http://dx.doi.org/10.1016/j.enconman.2016.09.044.

[10] Bellos, E. and C. Tzivanidis. Parametric analysis and optimization of a solar driven trigeneration system based on ORC and absorption heat pump. Journal of Cleaner Production 2017; 161: 493-509. http://dx.doi.org/10.1016/j.jclepro.2017.05.159.

[11] Bellos E, Tzivanidis C. Energetic and exergetic evaluation of a novel trigeneration system driven by parabolic trough solar collectors. Thermal Science and Engineering Progress 2018; 6: p. 41-47. https://doi.org/10.1016/j.tsep.2018.03.008.

[12] Bellos E, Tzivanidis C. Multi-objective optimization of a solar driven trigeneration system. Energy 2018; 149: 47-62. https://doi.org/10.1016/j.energy.2018.02.054.

[13] Bellos E, Tzivanidis C. Multi-objective optimization of a solar assisted heat pump-driven by hybrid PV. Applied Thermal Engineering, 2019; 149: 528-535. https://doi.org/10.1016/j.applthermaleng.2018.12.059.

[14] Bellos E, Tzivanidis C, Torosian K. Energetic, exergetic and financial evaluation of a solar driven trigeneration system. Thermal Science and Engineering Progress 2018; 7: 99-106. https://doi.org/10.1016/j.tsep.2018.06.001.

[15] Ghodbane M, Boumeddane B, Khechekhouche A, Benmenine D. Study of a solar air conditioning system with ejector International Journal of Energetica 2020; 5(1): 14-21. http://dx.doi.org/10.47238/ijeca.v5i1.115.

[16] Urbanucci L, Bruno JC, Testi D. Thermodynamic and economic analysis of the integration of high-temperature heat pumps in trigeneration systems. Applied Energy 2019; 238: 516-533. https://doi.org/10.1016/j.apenergy.2019.01.115.

[17] Arabkoohsar A, Andresen GB. Design and optimization of a novel system for trigeneration. Energy 2019; 168: 247-260. https://doi.org/10.1016/j.energy.2018.11.086.

[18] Yildırım C. Theoretical Investigation of a Solar Air Heater Roughened by Ribs and Grooves. Journal of Thermal Engineering 2018; 4(1): 1702-1712. https:/dx.doi.org/10.18186/journal-of-thermalengineering.365713.

[19] Kerme E, Kaneesamkandi Z. Performance Analysis and Design of Liquid Based Solar Heating System. Journal 
of Thermal Engineering 2015; 1(5): 182-191. https://dx.doi.org/10.18186/jte.02359.

[20] Pridasawas W, Lundqvist P. An exergy analysis of a solar-driven ejector refrigeration system. Solar Energy 2004; 76: 369-379. https://doi-org/10.1016/j.solener.2003.11.004.

[21] Varga S, Lebre PMS, Oliveira AC. CFD study of a variable area ratio ejector using R600a and R152a refrigerants. International journal of refrigeration 2013; 36: 157-165. http://dx.doi.org/10.1016/j.ijrefrig.2012.10.016.

[22] Pridasawas W, Lundqvist P. A year-round dynamic simulation of a solar-driven ejector refrigeration system with iso-butane as a refrigerant. International Journal of Refrigeration 2007; 30: 840-850. https://doiorg/10.1016/j.ijrefrig.2006.11.012.

[23] Ghodbane M, Boumeddane B. Numerical simulation of a solar-driven ejector refrigeration cycle coupled to a parabolic trough concentrator. International Journal of Chemical and Petroleum Sciences 2016; 5(1): 1-12. https://www.asjp.cerist.dz/en/article/4608.

[24] Bello E, Theodosiou IC, Vellios L, Tzivanidis C. Investigation of a novel solar-driven refrigeration system with ejector. Thermal Science and Engineering Progress 2018; 8: $284-295$. https://doi.org/10.1016/j.tsep.2018.09.005.

[25] Bellos E, Tzivanidis C. Assessment of linear solar concentrating technologies for Greek climate. Energy Conversion and Management 2018; 171: 1502-1513. https://doi.org/10.1016/j.enconman.2018.06.076.

[26] Bellos E, Tzivanidis C, Daniil I. Energetic and exergetic investigation of a parabolic trough collector with internal fins operating with carbon dioxide. International Journal of Energy and Environmental Engineering 2017; 8(2): 109-122. https://doi.org/10.1007/s40095-017-0229-5.

[27] Besagni G. Ejectors on the cutting edge: The past, the present and the perspective. Energy 2019; 170: 9981003. https://doi.org/10.1016/j.energy.2018.12.214.

[28] Besagni G, Mereu R, Inzoli F. Ejector refrigeration: A comprehensive review. Renewable and Sustainable Energy Reviews 2016; 53: 373-407. http://dx.doi.org/10.1016/j.rser.2015.08.059.

[29] Bellos E, Theodosiou IC, Vellios L, Tzivanidis C. Investigation of a novel solar-driven refrigeration system with ejector. Thermal Science and Engineering Progress 2018; 8: 284-295. https://doi.org/10.1016/j.tsep.2018.09.005.

[30] Bellos E, Tzivanidis C. Optimum design of a solar ejector refrigeration system for various operating scenarios. Energy Conversion and Management 2017; 154: 11-24. https://doi.org/10.1016/j.enconman.2017.10.057.

[31] Sumeru K, Sukri MF, Pratikto P, Badarudin A. Investigation of Modified Ejector Cycle on Residential Air Conditioner with Environmentally Benign Refrigerant of R290. Journal of Thermal Engineering 2020; 6(3): 297-312. https://dx.doi.org/10.18186/thermal.711539.

[32] Seçkin C. Investigation of The Effect of The Primary Nozzle Throat Diameter on The Evaporator Performance of an Ejector Expansion Refrigeration Cycle. Journal of Thermal Engineering 2018; 4(3): 1939-1953. https://dx.doi.org/10.18186/journal-of-thermal-engineering.408659.

[33] Kutlu Ç, Ünal S, and Erdinç MT. Thermodynamic Analysis of Bi-Evaporater Ejector Refrigeration Cycle Using R744 as Natural Refrigerant. Journal of Thermal Engineering 2016; 2(2): 735-740. https://dx.doi.org/10.18186/jte.78114.

[34] Dixit M, Arora A, Kaushik SC. Energy and Exergy Analysis of a Waste Heat Driven Cycle for Triple Effect Refrigeration. Journal of Thermal Engineering 2016; 2(5): 954-961. https://dx.doi.org/10.18186/jte.84533.

[35] Ghodbane M. Étude et optimisation des performances d'une machine de climatisation a éjecteur reliée à un concentrateur solaire (2017), Saad Dahleb University of Blida 1, Algeria: www.univ-blida.dz: Thesis available to the Library of the Faculty and the Central Library of the University. p. 200.

[36] Ghodbane M, Boumeddane B. Physical description of an isentropic flow in a Laval nozzle. https://www.cder.dz/download/Art19-1_5.pdf. Revue des Energies Renouvelables 2016; 19(1): 41-47.

[37] Ghodbane M, Boumeddane B. Engineering design and optical investigation of a concentrating collector: Case study of a parabolic trough concentrator J. Fundam. Appl. Sci. 2018; 10(2): 148-171. http://dx.doi.org/10.4314/jfas.v10i2.11.

[38] Ghodbane M, Boumeddane B. Optical modeling and thermal behavior of a parabolic trough solar collector in the Algerian sahara AMSE JOURNALS-AMSE IIETA, MMC_B 2017; 86(2): 406-426. https://doi.org/10.18280/mmc_b.860207.

[39] Ghodbane M, Boumeddane B. A parabolic trough solar collector as a solar system for heating water: a study based on numerical simulation International Journal of Energetica (IJECA) 2017; 2(2): 29-37. https://www.ijeca.info/index.php/IJECA/article/view/32.

[40] Ghodbane M, Benmenine D, Khechekhouche A, Boumeddane B. Brief on Solar Concentrators: Differences and Applications. Instrumentation Mesure Metrologie 2020; 19(5): 371-378. 
https://dx.doi.org/10.18280/i2m.190507.

[41] Bellos E. Progress in the design and the applications of Linear Fresnel Reflectors - A critical review. Thermal Science and Engineering Progress 2019; 10: 112-137. https://doi.org/10.1016/j.tsep.2019.01.014.

[42] Bellos E, Tzivanidis, Papadopoulos A. Enhancing the performance of a linear Fresnel reflector using nanofluids and internal finned absorber. Journal of Thermal Analysis and Calorimetry, 2019. 135(1): p. 237255. https://doi.org/10.1007/s10973-018-6989-1.

[43] Bellos E, Tzivanidis C. Multi-criteria evaluation of a nanofluid-based linear Fresnel solar collector. Solar Energy 2018; 163: 200-214. https://doi.org/10.1016/j.solener.2018.02.007.

[44] Said Z, Ghodbane M, Sundar LS, Tiwari AK, Sheikholeslami M, Boumeddane B. Heat transfer, entropy generation, economic and environmental analyses of linear Fresnel reflector using novel rGO-Co3O4 hybrid nanofluids. Renewable Energy 2021; 165(Part 1): 420-437. https://doi.org/10.1016/j.renene.2020.11.054.

[45] Hussein AK, Ghodbane M, Said Z, Ward RS. The Effect of the Baffle Length on the Natural Convection in an Enclosure Filled with Different Nanofluids. Journal of Thermal Analysis and Calorimetry 2020. https://doi.org/10.1007/s10973-020-10300-1.

[46] Bellos E, Tzivanidis C, Papadopoulos A. Optical and thermal analysis of a linear Fresnel reflector operating with thermal oil, molten salt and liquid sodium. Applied Thermal Engineering 2018; 133: 70-80. https://doi.org/10.1016/j.applthermaleng.2018.01.038.

[47] Bellos E, Tzivanidis C, Papadopoulos A. Daily, monthly and yearly performance of a linear Fresnel reflector. Solar Energy 2018; 173: 517-529. https://doi.org/10.1016/j.solener.2018.08.008).

[48] Bellos E, Mathioulakis E, Tzivanidis C, Belessiotis V, Antonopoulos KA. Experimental and numerical investigation of a linear Fresnel solar collector with flat plate receiver. Energy Conversion and Management 2016; 130: 44-59. https://doi.org/10.1016/j.enconman.2016.10.041.

[49] Roostaee A, Ameri M. Effect of Linear Fresnel Concentrators field key parameters on reflectors configuration, Trapezoidal Cavity Receiver dimension, and heat loss. Renewable Energy 2019; 134: 1447-1464. https://doi.org/10.1016/j.renene.2018.09.053.

[50] Pulido-Iparraguirre D al. Optimized design of a Linear Fresnel reflector for solar process heat applications. Renewable Energy 2019; 131: 1089-1106. https://doi.org/10.1016/j.renene.2018.08.018.

[51] Marugán-Cruz C, Serrano D, Gómez-Hernández J, Sánchez-Delgado S. Solar multiple optimization of a DSG linear Fresnel power plant. Energy Conversion and Management 2019; 184: 571-580. https://doi.org/10.1016/j.enconman.2019.01.054.

[52] Barbón A, Sánchez-Rodríguez JA, Bayón L, Bayón-Cuelic C. Cost estimation relationships of a small scale linear Fresnel reflector. Renewable Energy 2019; 134: 1273-1284. https://doi.org/10.1016/j.renene.2018.09.060.

[53] Barbón A, Sánchez-Rodríguez JA, Bayón L, Barbón N. Development of a fiber daylighting system based on a small scale linear Fresnel reflector: Theoretical elements. Applied Energy 2018; 212: 733-745. https://doi.org/10.1016/j.apenergy.2017.12.071.

[54] Ghodbane M, Bellos E, Said Z, Boumeddane B, Khechekhouche A, Sheikholeslami M, Ali ZM. Energy, Financial and Environmental investigation of a direct steam production power plant driven by linear Fresnel solar reflectors. Journal of Solar Energy Engineering 2021; 143(2): 021008 (11 pages). https://doi.org/10.1115/1.4048158.

[55] Ghodbane M, Boumeddane B, Said Z, Bellos E. A numerical simulation of a linear Fresnel solar reflector directed to produce steam for the power plant. Journal of Cleaner Production 2019; 231: 494-508. https://doi.org/10.1016/j.jclepro.2019.05.201.

[56] Said Z, Ghodbane M, Hachicha AA, Boumeddane B. Optical performance assessment of a small experimental prototype of linear Fresnel reflector Case Studies in Thermal Engineering 2019; 16: 100541. https://doi.org/10.1016/j.csite.2019.100541.

[57] Moghimi MA, Craig KJ, and Meyer JP, Optimization of a trapezoidal cavity absorber for the Linear Fresnel Reflector. Solar Energy 2015; 119: 343-361, http://dx.doi.org/10.1016/j.solener.2015.07.009.

[58] Moghimi MA, Craig KJ, and Meyer JP, A novel computational approach to combine the optical and thermal modelling of Linear Fresnel Collectors using the finite volume method. Solar Energy 2015; 116: 407-427, http://dx.doi.org/10.1016/j.solener.2015.04.014.

[59] Ghodbane M, Boumeddane B, Largot S. Simulation Numérique d'un Concentrateur Cylindro-Parabolique en El Oued, Algérie. International Journal of Scientific Research \& Engineering Technology (IJSET) 2015; 3(2): 68-74.

[60] Bonnet S, Alphilippe M, Stouffs P. Conversion thermodynamique de l'énergie solaire dans des installations de faible ou de moyenne puissance: Réflexion sur choix du meilleurs degré de concentration. in 11 ème journée 
Journal of Thermal Engineering, Research Article, Vol. 7, No. 1, pp. 172-189, January, 2021

internationales de thermique. 2003. Revue d'énergie renouvelable.

[61] Duffie JA, Beckman WA. Solar Engineering of Thermal Processes. 4th ed. Wiley; 2013.

[62] Wagner, M.J. Results and comparison from the sam linear fresnel technology performance model. in World Renewable Energy Forum Denver, Colorado May 13-17. National Renewable Energy Laboratory (NREL) 2012.

[63] Diebel J, Norda J, Kretchmer O. Usual weather, July 17 in Oued Souf, Algeria. Weather Spark (2019). https://fr.weatherspark.com 